\title{
Gamification in modern education
}

\section{Gamificación en la educación moderna}

\author{
Julia M. Tsarapkina \\ julia_carapkina@mail.ru \\ https://orcid.org/0000-0002-3807-4211 \\ Russian State Agrarian University - Moscow Timiryazev Agricultural Academy, Moscow, \\ Russia. \\ Olga I. Vaganova \\ vaganova_o@rambler.ru \\ https://orcid.org/0000-0001-8347-484X \\ Minin Nizhny Novgorod State Pedagogical University, Nizhny Novgorod, Russia \\ Anna V. Lapshova \\ any19.10@mail.ru \\ https://orcid.org/0000-0001-7017-3589 \\ Minin Nizhny Novgorod State Pedagogical University, Nizhny Novgorod, Russia \\ Margarita I. Koldina \\ ritius@mail.ru \\ https://orcid.org/0000-0002-3368-7297 \\ Minin Nizhny Novgorod State Pedagogical University, Nizhny Novgorod, Russia \\ Ivan A. Sedov \\ ivansedof@yandex.ru \\ https://orcid.org/0000-0003-3904-7562 \\ Minin Nizhny Novgorod State Pedagogical University, Nizhny Novgorod, Russia
}

Recibido: $23 / 08 / 21$

Aceptado: 19/10/21

\section{Abstract}

Purpose of the article is analysis of the experience of gamification in modern professional education. The article presents an analysis of the project activities of senior students of higher educational institutions against the background of gamification of the educational process. The study made it possible to determine the role of gamification in modern vocational education. Gamification acts as a means of promoting deeper involvement of students in the educational process, their achievement of higher indicators and results. Its development in modern education expands the opportunities for training students.

Key Words: gamification, educational process, higher educational institution, competencies, gaming technologies. 


\section{Resumen}

El objeto del artículo es el análisis de la experiencia de la gamificación en la educación profesional moderna. El artículo presenta un análisis de las actividades del proyecto de estudiantes de último año de instituciones de educación superior en el contexto de la gamificación del proceso educativo. El estudio permitió determinar el papel de la gamificación en la educación profesional moderna. La gamificación actúa como un medio para promover una mayor implicación de los estudiantes en el proceso educativo, su consecución de mejores indicadores y resultados. Su desarrollo en la educación moderna amplía las oportunidades de formación de los estudiantes.

Palabras clave: gamificación, proceso educativo, institución de educación superior, competencias, tecnologías de juego.

\section{Introduction}

The education system, responding to social changes and needs, includes innovative tools, which include the use of electronic educational platforms, applications for webinars and other educational purposes, and other tools for improving the educational process.

The modern labor market requires specialists capable of creative and prompt solution to professional tasks. To do this, educational institutions use tools that allow them to bring the educational process as close as possible to real professional conditions (Tsarapkina et al., 2021).

Gamification acts as a tool in the modern educational process, contributing to a deeper involvement of students in the educational process, achieving higher indicators and results. Gamification is considered both as the implementation of game technologies and as separate electronic tools that activate the learning process.

The concept of gamification is associated with a computer game intended for entertainment purposes, but today it is an integral part of the educational process (Rudenko et al., 2021). The tutorial game features gameplay that allows the player to interact with the game. That is, it is a control panel (Vaganova et al., 2019). In professional education, the role of gameplay is played by the tools provided by the electronic platform and applications. Students can interact remotely by developing a project at any stage (Shashlo et al., 2018). Students can send files to each other, edit documents, communicate via video conferences, and receive timely teacher advice (Yarygin et al., 2019).

Gamification allows you to make the training of students more effective (Ponachugin \& Lapygin, 2019). The introduction of the gamification process will allow students to form an experience of solving professional problems in the learning process, to form the skill 
of interaction in a competitive environment, the skill of working in a team, systematic thinking and the necessary competencies for professional activity (Aniskin et al., 2020).

Studying the possibilities of gamification and the experience of its implementation in education will improve the training of highly qualified specialists who can adapt to the implementation of professional activities in rapidly changing conditions, solve problems in a non-standard way, show independence and creativity (Pinkovetskaia et al., 2020).

\section{Theoretical framework}

Gamification is a game practice. This is a tool that challenges the student, forcing them to improve their skills and professional competencies. Each subsequent step in the game allows the student to better master the material and better navigate their professional activities (Vaganova et al., 2020). The essence of gamification is the use of game mechanics that arouse the student's interest (Shcerbakova \& Shcerbakova, 2019).

In the work of $\mathrm{V}$. V. Matonin, gamification is revealed as the process of using game methods in non-game environments, including in the environment of professional education (Matonin, 2017). The table shows the main aspects of gamification proposed by V. V. Matonin.

\section{Table 1.}

The main aspects of gamification in the educational process.

\begin{tabular}{ll}
\hline Aspect & Characteristic \\
\hline Dynamic element & $\begin{array}{l}\text { Use in the process of preparing students } \\
\text { of various scenarios that require attention } \\
\text { and concentration of students in real time }\end{array}$ \\
\hline Game mechanics & $\begin{array}{l}\text { Use of game-specific scenarios including } \\
\text { awards, titles, bonuses and other game } \\
\text { elements }\end{array}$ \\
\hline Aesthetic element & $\begin{array}{l}\text { Creation of emotional engagement } \\
\text { through visual effect (for example, the } \\
\text { simplicity and ease of use of the interface } \\
\text { of an electronic tool for remote interaction) }\end{array}$ \\
\hline Social element & $\begin{array}{l}\text { Ensuring inter-user interaction to fulfill the } \\
\text { established tasks }\end{array}$ \\
\hline
\end{tabular}

In the implementation of gamification in education, V.V. Matonin distinguishes cognitive, emotional and social components, the characteristics of which are presented in the table. 
Table 2.

Components of gamification in the educational process.

\section{Component}

Cognitive

Emotional

Social

\section{Characteristic}

Completing a task in the form of a socalled quest can be carried out in different ways, students can find several options for solving problems, with the help of which the student can independently determine the level of mastery of a particular material, whether he can solve problems in several ways

Stimulating competitive behavior in the study of specific disciplines, activating the student's desire to achieve the highest results

In the process of playing activity, the student has the opportunity to perform different roles and determine his ability to implement them

The main elements of gamification as a process were proposed in the work of A.S. Potapova. They are shown in the figure. A.S. Potapova combines the essence of gamification in three elements (Potapova, 2019).

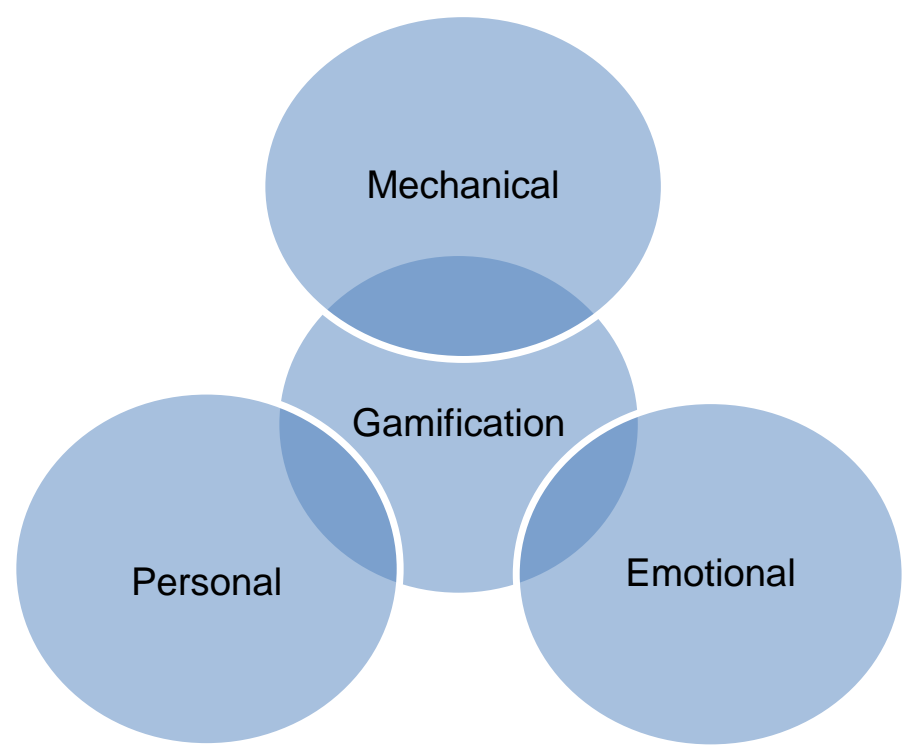

Fig. 1. The main elements of gamification. 
The mechanical element implies the student's mastering of the mechanism of the instrument, immersing him in educational activity, its goals and objectives. The personal element allows the student to be directly involved in an active learning process (Demidov et al., 2016a). Each of the students is aware of their importance in team activities, each of the students makes their important contribution to the result (Misakov et al., 2019). The emotional element means the need to create psychological comfort and a favorable emotional atmosphere in the process of completing tasks (Kidina, 2020). Students also immerse themselves in a state called "flow" - a state of complete concentration on the tasks at hand (Klimov et al., 2019). The teacher formulates goals, organizes clear feedback, allowing students to carry out work by requirements (Pichugina \& Bondarchuk, 2019).

It should be noted that many authors emphasize the presence of awards, bonuses and points in the gamification process as mandatory elements (Demidov et al., 2016a).

Modern game and gaming technologies allow you to create certain conditions for the most effective achievement of the assigned tasks. Gamification allows simulating game reality (Bulaeva, et al., 2018). The student takes on different roles and acts based on the prevailing circumstances, thereby gaining experience in real professional activities (Kharytonov et al., 2019).

The step-by-step process of mastering the educational material in the process of completing tasks should be accompanied by the inclusion of the following components: mechanics (points, passing levels, rating (Demidov et al., 2016b), implementation of constant feedback); an award confirming the status of the winner; measurement (the principle of evaluating results); behavior (increasing user loyalty, which allows you to make the process the most emotionally favorable and effective) (Ivanova \& Korostelev, 2019) .

Gamification in the modern educational process contributes to the development of memory and attention, flexibility of thinking, critical thinking, and the formation of professional competencies (Braslavska \& Rozhi, 2020).

G.A. Bannykh distinguishes several areas of gamification in his work. The table shows the main directions (Bannykh, 2017). 
Revista de Tecnología de Información y Comunicación en Educación • Volumen 15, N 3. Septiembre-diciembre 2021

Table 3.

Directions of gamification.

Direction

Play as a way to create innovation

The game is a way of modeling professional situations and mastering practical skills

Play as a way to conduct a discussion

\section{Characteristic}

In the process of playing activities, students create a project, the finished project of which can be introduced into the activities of any organization to increase its competitiveness

Simulation of professional activity allows students to quickly adapt to real professional conditions and apply existing experience to achieve the best results and adjust their activities

Organization of interaction between students in real time and in a distance format. Students learn to build a dialogue, give arguments, resolve conflicts

The number of directions presented is not exhaustive. The directions of gamification are expanding and there are more of them in educational activities.

\section{Methodology}

The article presents an analysis of the project activities of students of higher educational institutions (Russian State Agrarian University - Moscow Timiryazev Agricultural Academy, Minin Nizhny Novgorod State Pedagogical University) for 2019 and 2020. Promising projects of students that can be used in the activities of real organizations and companies are highlighted.

An analysis of the activities of three educational institutions revealed an increase in" viable " projects among students over the period 2019-2020.

A survey conducted among students of 3-4 courses allowed us to determine the role of gamification in project activities. The students were offered a list of questions concerning the positive and negative aspects of gamification. They had to agree with the statement or refute it by answering: yes; rather yes than no; rather no than yes; no. Each answer is assigned a corresponding score.

\section{Results and discussion}

In the training of students of higher educational institutions, innovative solutions are used to motivate students to professional self-improvement. The elements of gamification 
provide ample opportunities for this. At various stages of training, universities use challenges, ranks, awards, and statuses (Dobudko et al., 2019).

As an element of gamification, we can consider a portfolio of achievements. Students receive points for participating in various activities: scientific, sports, social, and cultural (Nagovitsyn et al., 2020). Each of the students has the opportunity to control each of the areas of training in this way and fill in the gaps on time. The accumulated points motivate the student to study the material in more depth. The award is an increased student scholarship.

The training uses a kind of "leadership panel" where students see their achievements in the form of grades. The points are displayed in the section on the electronic platform.

The competitive game element encourages students to be more active, striving to achieve the best results.

Modern gaming technologies involve the use of a significant number of electronic tools.

Students carry out projects, case studies, and conduct team research. Cloud storage is used, from where students can freely take files to complete tasks. Operational issues are resolved via Viber or WhatsApp. Conferences and consultations are held via Zoom. Electronic educational platforms, such as Moodle, are used to discuss the most ambitious topics and perform more extensive tasks. To visualize the materials obtained, the applications that are most convenient for the students themselves are used.

At the same time, gamification in the educational process of the university supports the process of self-improvement, the desire to overcome obstacles, achieve new goals, adapt to operational and effective team activities, and make decisions in conditions of time scarcity.

For remote execution of various tasks and projects, a Google document is often used, which can be edited by all team members who have access to it (Kiseleva et al., 2019).

For two years at universities (Russian State Agrarian University - Moscow Timiryazev Agricultural Academy, Minin Nizhny Novgorod State Pedagogical University) in the course of playing activities with the use of electronic tools, students prepared projects aimed at solving significant problems in various areas of society's life. The most significant ones are shown in the figure. 


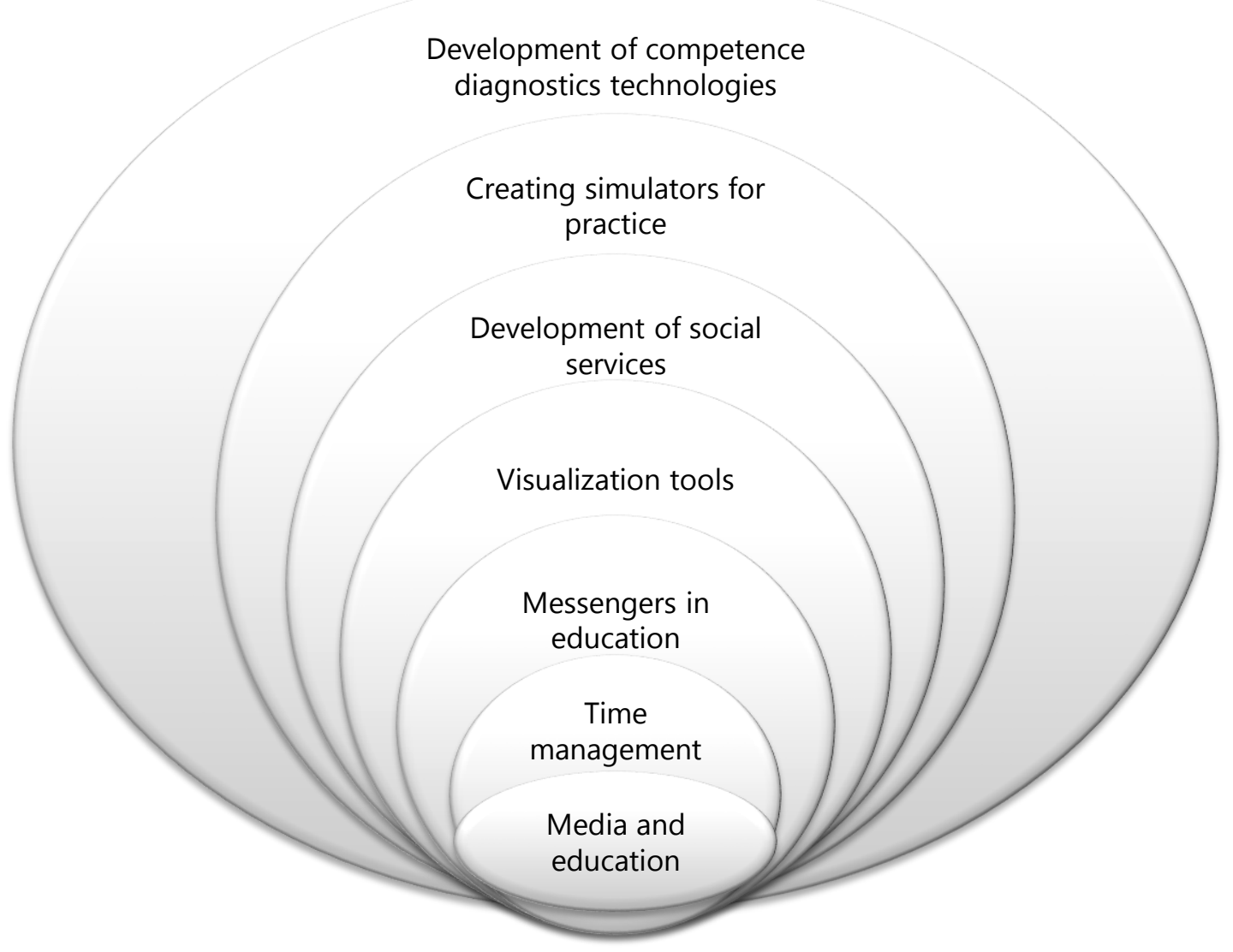

Fig. 2. Promising student projects developed using gamification tools for the period 20192020

It is also worth noting the growth in the number of projects carried out using electronic gamification tools. As the students themselves note, these tools allow them to interact most effectively, quickly solve problems and communicate with other subgroups. At the same time, each subgroup sees the results of its competitors and therefore tries to improve their results.

The process is controlled by a curator or teacher, so there is a "healthy" competition and a positive psychological climate.

Among the students of 3-4 courses (for the study, the respondents of the senior courses were selected as the most adapted to the educational process and implemented innovations) of higher educational institutions, a survey was conducted that allowed us to determine the role of gamification in project activities. The students were offered a list of questions concerning the positive and negative aspects of gamification. They had to agree with the statement or refute it by answering: yes; rather yes than no; rather no than yes; no. Among the questions were the following: "Do you think that the development of gamification has a positive impact on the educational process?"; "Are remote 
technologies convenient to use in the implementation of projects and cases?"; " Is it possible to establish the process of game interaction in the subgroup using electronic technologies?"; "Is it possible to quickly establish the process of game interaction through electronic tools? "; Each answer is assigned a corresponding score. The results are shown in Figure 3.

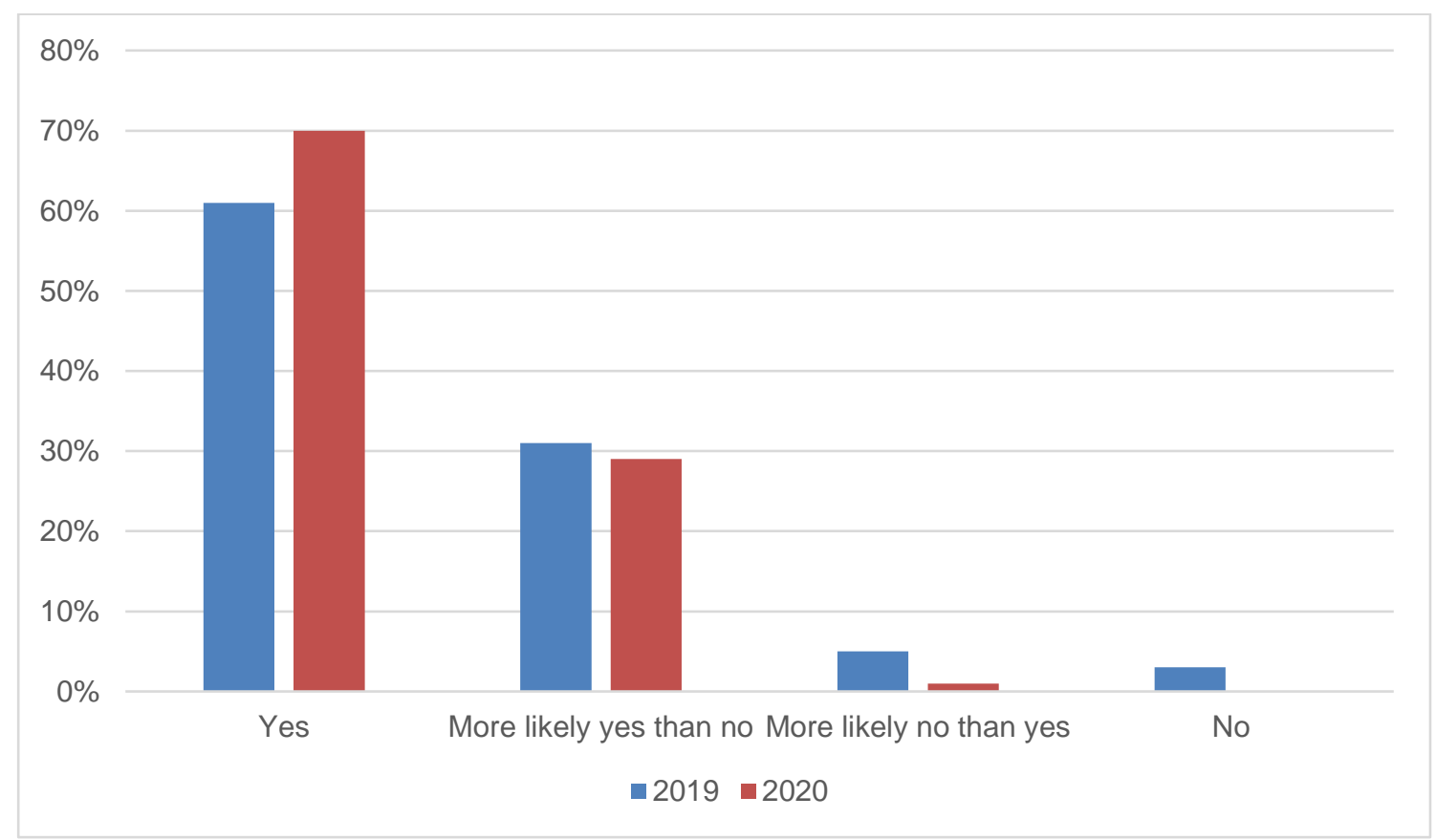

Fig. 3. Results of the survey of senior students for two years.

Based on the data obtained, we can state that the majority of respondents noted the positive impact of gamification. Although students are not always able to quickly establish a remote interaction process for technical reasons.

In 2020, in the context of the need to maintain social distance and mass transition to distance learning, a high value of positive responses was revealed. The rapid response of educational institutions to the situation allowed us to change the conditions of training and continue to develop innovative processes. The gamification of modern education continues and improves.

\section{Conclusions}

Gamification in modern education is a multidimensional process that includes the use of various electronic tools, game technologies, implemented both in the classroom and in a remote format.

The conducted research allows us to detect the positive effect of the introduction and development of gamification in the educational process. There is an increase in projects 
carried out by students with the help of gamification tools that make the educational process more active and involve each student in solving professional problems.

The development of gamification makes it possible to expand the possibilities of training students and to form the necessary competencies for the implementation of professional activities, to prepare specialists capable of creative and operational solution of professional tasks.

\section{Bibliographic references}

Aniskin, V. N., Korostelev, A. A., Lvovna, B. A., Kurochkin, A. V., \& Sobakina, T. G. (2020). Teaching potential of integrated learning technologies Smart, Stem and Steam. Revista De La Universidad Del Zulia, 11(29), 328-336.

Bulaeva, M. N., Vaganova, O. I., Koldina, M. I., Lapshova, A. V., \& Khizhnyi, A.V. (2018). Preparation of Bachelors of Professional Training Using MOODLE. Advances in intelligent systems and computing, 622, pp. 406-411.

Bannykh, G.A. (2017) Gamification in university education: a comparative analysis of practices. Materials of the III International Scientific and Practical Conference "Strategies for the Development of Social Communities, Institutions and Territories". Ekaterinburg: Ural Publishing House, University, 277-280. (In Russian).

Braslavska, O. V., \& Rozhi, I. G. (2020). Peculiarities of innovative learning in a modern educational environment. Balkan Scientific Review, 4, 2 (8), 24-26.

Dobudko T.V., Korostelev A.A., Gorbatov S.V., Kurochkin A.V., \& Akhmetov L.G. (2019). The organization of the university educational process in terms of digitalization of education. Humanities and Social Sciences Reviews, 7(4), pp. 1148-1154.

Demidov, A.A. \& Tretyakov A.L. (2016a). A network model of centers for ethical and legal education and civil-patriotic education and media education centers based on school libraries: the need to create, opportunities and real prospects, Media Education (Mediaobrazovanie), 3, pp. 16-22.

Demidov, A.A., \& Tretyakov, A.L. (2016b) Centers for ethical and legal information and media education based on the school library - an innovation in the implementation of the Federal State Educational Standard and infrastructure for the development of information and legal culture of children and youth. Media Education (Mediaobrazovanie), 2, pp. 21-33.

Ivanova, N., \& Korostelev, A. (2019). The impact of competitive approach on students' motivation in sport. Amazonia Investiga, 8(18), 483-490. Retrieved from https://amazoniainvestiga.info/index.php/amazonia/article/view/362

Kidina I. M. (2020). Management of the pedagogical collective in the conditions of implementing distance learning. Baltic Humanitarian Journal. (Baltic Humanitarian Journal), Vol. 9 No 4 (33), pp. 93-96.

Klimov A. A., Zarechkin E. Y., \& Kupriyanovsky V. P. (2019). About the digital ecosystem of a modern university. Modern Information Technology and IT Education, 15 (4), 815-824. 
Kharytonov, E., Kharytonova, O., Tolmachevska, Y., Fasii, B., \& Tkalych, M. (2019). Information Security and Means of Its Legal Support. Amazonia Investiga, 8(19), 255-265. https://amazoniainvestiga.info/index.php/amazonia/article/view/227

Kiseleva, O., Lebedev, A., Pinkovetskaia, I., Rojas-Bahamón, M., \& Arbeláez Campillo, D. (2019). Specialization and concentration of small and medium enterprises employees: Russian data. Amazonia Investiga, 8(20), 6-15. https://amazoniainvestiga.info/index.php/amazonia/article/view/59

Misakov, V., Tsurova, L., Yandarbayeva, L., Tkhamadokova, I., \& Gapurovna, G. (2019). Certification of a regional economic complex as a highly effective tool for analysis and diagnostics of its development. Amazonia Investiga, 8(20), 451-458. Retrieved from https://amazoniainvestiga.info/index.php/amazonia/article/view/174

Matonin, V. V. (2017). Trends in modern education: gamification. Bulletin of the Buryat State University. Education. Personality. Society, (2), 36-40. URL: https://cyberleninka.ru/article/n/trendy-sovremennogo-obrazovaniya-geimifikatsiya.

Nagovitsyn, R. S., Vaganova, O. I., Kutepov, M. M., M. L. N., Kosenovich, O. V, Moeseev, Yu. V., Vorotova, M. S., \& Osipov, A. Y. (2020). Interactive Technologies in Developing Student's Motivation in Physical Education and Sport. International Journal of Applied Exercise Physiology, 9(6), 78-85.

Potapova, A.C. (2019). Gamification in education: characteristics and elements. Collection of articles of the XXIX International Scientific Conference "Language and Culture" (October 16-18, 2018). Tomsk: Tomsk State University Publishing House, 1, 200-205. (In Russian).

Pichugina, G.A., \& Bondarchuk, A.I. (2019). Structure of the training case in the organization of the educational process. Humanitarian Balkan Research, 2(4), pp. 5-7.

Pinkovetskaia, I., Berezina, N., \& Sverdlikova, E. (2020). The main reasons for the exit of entrepreneurs from business. Amazonia Investiga, 9(26), 68-73. https://doi.org/10.34069/Al/2020.26.02.7

Pinkovetskaia, I., Kryukova, L., Arbeláez, D., \& Rojas-Bahamon, M. (2019). Female Entrepreneurship: Types of Economic. Activity. Tarih kultur ve sanat arastirmalari dergisi-journal of history culture and art research, 8(2), 253-265. DOI: 10.7596/taksad.v8i2.2153

Ponachugin, A.V., Lapygin, Yu.N. (2019). Digital Educational Resources of the University: Design, Analysis and Expertise. Vestnik of Minin University, 7 (2), 5. (in Russ)

Rudenko, I. V., Bystrova, N. V., Smirnova, Zh. V., Vaganova, O. I., Kutepov, M. M. (2021). Modern technologies in working with gifted students. Propositos $y$ representaciones, 9. № SI, Article number e818.

Shashlo, N., Petruk, G., \& Korostelev, A. (2018). Determinants of integration interaction among the subjects of the entrepreneurial innovation ecosystem of macro region. Amazonia Investiga, 7(13), 351-363. Retrieved from https://amazoniainvestiga.info/index.php/amazonia/article/view/569

Shcerbakova, E.V., \& Shcerbakova, T. N. (2019). Experience of Use of Remote Computer Technologies at The Organization of Independent Work of Students in The 
Revista de Tecnología de Información y Comunicación en Educación • Volumen 15, № 3. Septiembre-diciembre 2021

Conditions of a Mark and rating system. Baltic Humanitarian Journal. (Baltic Humanitarian Journal), Vol. 8, No 4 (29), pp. 192-195.

Tsarapkina, J. M., Plahina, L. N., Konoplyuk, N. V., Vaganova, O. I., \& Lapshova, A. V. (2021). The formation of bachelors' digital competencies at the university. Propositos y representaciones, 9, № SI, Article number e811.

Vaganova, O.I., Korostelev, A.A., Smirnova, Z.V., Abramova, N.S., \& Dolmatov, S.N. (2019). Improving teachers' professionalism through the development of creativity. International Journal of Innovative Technology and Exploring Engineering, 8(8), pp. 630-634.

Vaganova, O., Petrozitskaya, I., Snatovich, A., Odarich, I., \& Kirillova, I. (2020). Heuristic technologies of training in professional education. Amazonia Investiga, 9(27), 509-517. https://doi.org/10.34069/Al/2020.27.03.55

Yarygin, O.N., Korostelev, A.A., Akhmetov, L.G., \& Maseleno, A. (2019). Modeling of competence as a tool of goal setting for education in modern society. International Journal of Recent Technology and Engineering, 7(6), pp. 72-77. 